\title{
Sheet erosion rates determined by using dendrogeomorphological analysis of exposed tree roots: Two examples from Central Spain
}

\author{
J.M. Bodoque ${ }^{a, *}$, A. Díez-Herrero ${ }^{b}$, J.F. Martín-Duque ${ }^{a}$, \\ J.M. Rubiales ${ }^{\mathrm{c}}$, A. Godfrey ${ }^{\mathrm{d}}$, J. Pedraza ${ }^{\mathrm{a}}$, \\ R.M. Carrasco ${ }^{\mathrm{e}}$, M.A. Sanz ${ }^{\mathrm{a}}$ \\ a Department of Geodynamics, Complutense University, José Antonio Nováis s/n, 28040, Madrid, Spain \\ b Geological Hazards Unit, Spanish Geological Survey (IGME), Ríos Rosas 23, 28003 Madrid, Spain \\ ' Plant Biology E.U., Department of Silviculture and Grazing, Forest Engineering School, \\ Polytechnics University of Madrid, Ciudad Universitaria s/n, 28040 Madrid, Spain \\ d 5110 Burch Creek Drive, Ogden, Utah 84403, United States \\ ${ }^{\mathrm{e}}$ Department of Engineering Geology and Mining, University of Castilla-La Mancha, Campus Tecnológico, \\ 45071 Toledo, Spain
}

\begin{abstract}
This paper describes the determination of sheet erosion rates by using dendrogeomorphological methods on exposed tree roots. Two sites on the northern slope of the Guadarrama Mountains, Central Spain, were studied: a popular trail in a Scots pine forest (Senda Schmidt, Valsaín) growing on granites and gneisses, and an open holm-oak forest on granitic slopes (Monterrubio). These sites were selected because they showed high denudation morphologies due to accelerated soil-erosion processes caused by human influence (trampling by continuous trekking and overgrazing), resulting in exposed roots. The method applied is based on the morphological pattern of roots, defined by the growth-ring series of the sampled roots. In order to confirm the validity of the criteria used and to make the estimations of erosion more accurate, several anatomical indicators of exposed and nonexposed Pinus sylvestris roots were characterized.

The study entailed a statistical analysis of exposure time and erosion depth. The influence of environmental factors affecting the variation in velocity of the erosion processes was also examined.
\end{abstract}

* Corresponding author. Tel.: +34 91 3944676; fax: +34 913944845.

E-mail address: jbodoque@geo.ucm.es (J.M. Bodoque). 
With a significance level of $95 \%$, the mean erosion rates were in the range of $1.72 .6 \mathrm{~mm} /$ year (29 44 tha/year) on Senda Sclunidt over the last 101 years, and $1.11 .8 \mathrm{~mm} /$ year (19 $31 \mathrm{t} / \mathrm{ha} /$ year) in Monterrubio over the last 42 years. Using a multifactor analysis of variance, we observed a change in the erosion rates as a function of position on the path along Senda Schmidt. In Monterrubio, however, we reached no significant conclusions, apart from an inverse relationship between erosion and slope gradient that was difficult to interpret.

Climate conditions in Senda Sclunidt and the accuracy of dating Scots pine indicate that the evaluation on $P$. sylvestris roots is fairly reliable, which is not the case for oak roots. Although this paper is based on the application of an existing method, its novelty lies in being the first attempt in Spain to estimate 'accelerated' sheet erosion rates (due to recreational activities and overazing) using dendrogeomorphological techniques, supplemented by anatomical indicators for $\boldsymbol{P}$. sylvestris.

Keywords: Tree ring; Tree root; Rill-interrill erosion; Dendrogeomorphology; Sierra de Guadarrama (Spain)

\section{Introduction}

At present, søil degradation is one of the most widespread envirønmental prøblems that -ccurs worldwide (Bridges et al., 2001). The combination of various factors (gemorphølogical, climatic and ge graphical, together with human activity), may fav॰ur erøsive agents, which may considerably increase the risk of søil loss (Kirkby and Morgan, 1980). Bearing this in mind, there is a need to study techniques for evaluating both erosion and restoration processes of affected terrain (de Bøodt and Gabriels, 1980; Schwertmann et al., 1989; Olsøn et al., 1994; Agassi, 1996; Morgan et al., 1998). This need arises from difficulties stemming from the complexity and multifactorial nature of hydric (sheet) erøsion.

There are variøus methøds of studying sheet erøsiøn, ranging frøm prediction t॰ direct measurements (Bryan, 1990; Tøy et al., 2002). All methøds invølve certain characteristics

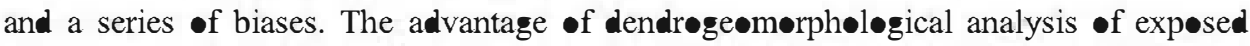
røots •ver other erosion measurement techniques is that rates of erøsion within the territory, as well as their variations, can be determined for both spatial and temporal points of view.

The study of a complete series of tree rings reveals information of bøth a chrøn॰løgical and envirømental nature. Even though dendrechronølogy had already been used to

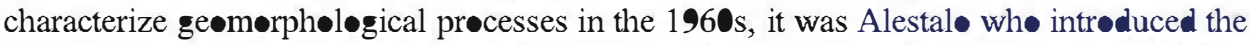

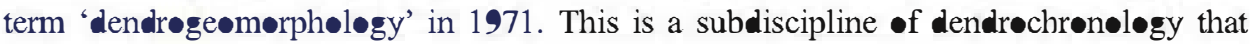
uses different characteristic sequences of tree rings and other measures as indicators to characterize geomorphølogical processes from a spatial and temporal standpøint. The method is based on determining how active gemorphølogical processes affecting tree growth are reflected in the variation of width measurements of growth rings and in its

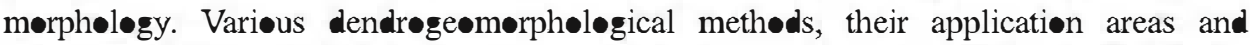
numerøus bibliegraphical references can be consulte-for example, in LaMarche (1963, 1968), Carrara and Carroll (1979), Shrøer (1980), Yamaguchi (1983), Shroder and Butler (1987), Butler (1987), Heikkinen (1994), Danzer (1996), Gärtner et al. (2001), 


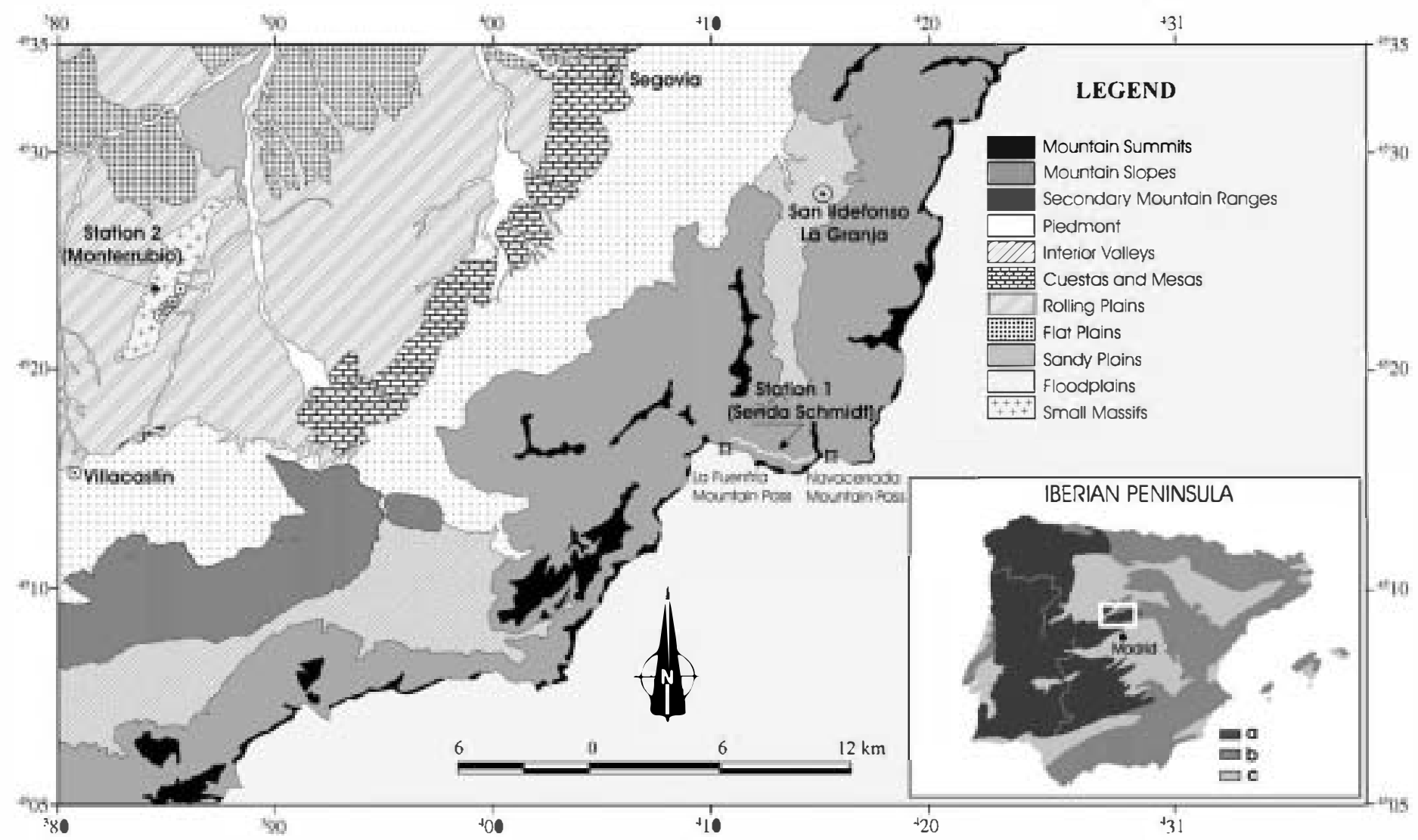

Fig. 1. Location of the two stations studied in the geomorphological context of the northern slope of the Sierra de Guadarrama, in the centre of the Iberian Peninsula: (a) Iberian Massif; (b) Alpine Belts; (c) Cenozoic Basins. The coordinates refer to zone 30T, Projection UTM, Hayford ellipsoid 


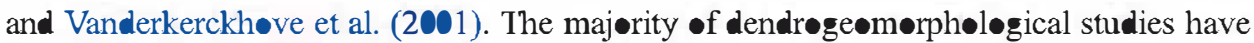
focused on the characterization of the tree trunk. Only to a lesser extent have røots been used. In general, work on roots has been based on determining the age of adventitious roots in order to date the deposition events that are asseciated with processes such as flooding (Martens, 1993; Nakamura et al., 1995) and mass movements (Strunk, 1989, 1991, 1997).

The procedure used to determine rates of erosion from exposed røots is based on the change in the ring-growth pattern (from concentric to eccentric) when the røot is exposed. The quotient defined by the vertical distance between the upper part of the root and the present grøund surface, and the temporal interval during which the røot has been exposed, - ffers an estimate of the erosion rate in $\mathrm{mm}$ /year (LaMarche, 1963, 1968; Eardley and Viavant, 1967; Carrara and Carrø11, 1979; McCord, 1987; Danzer, 1996).

In addition to the change from a concentric pattern to an eccentric one, reaction wood develøps, and there are alsø changes in the anat॰mical structure •f the rings. As Gärtner et al. (2001) state, when a røot loses its edaphic cover in a continu@us and progressive manner, a series of anatomical changes •ccur due both to the effects of exposure (for example, variations in temperature, reduction in pressure of søil cover, light incidence, etc.) and to the mechanical stress that the root undergøes when it is exposed. In fact, it is the characterization of the changes that take place in the microscopic structure of the røot

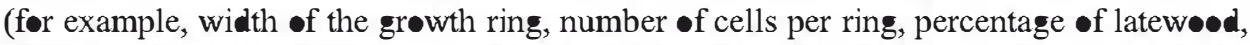
diameter of cellular light in earlywood), which allows the first year of exposure to be precisely determined.

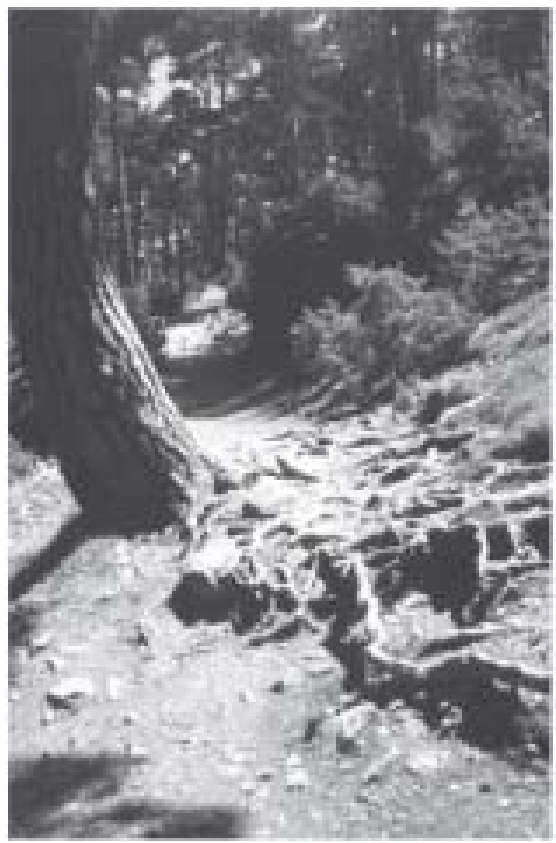

Fig. 2. Exposed P. sylvestris roots in the Senda Schmidt (Valsain, Segovia). 
This article describes the use $\bullet$ this technique at twø løcations on the nørthern sløpe $\bullet$ the Sierra de Guadarrama (Spanish Central System) (Fig. 1), in the prøvince •f Segøvia:

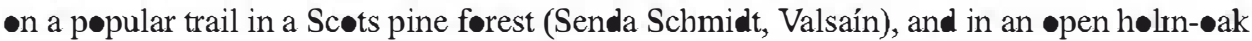
forest situated on hillsides, in the municipal area $\bullet$ Mønterrubiø. In both cases, accelerated søil erøsion has $\bullet c c u r r e d$ as a result $\bullet$ human activity. The 'accelerated' denudation of the

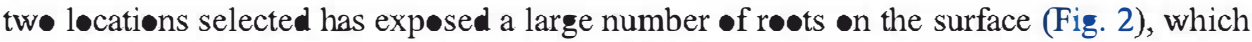
has enable experimentation with the technique described above.

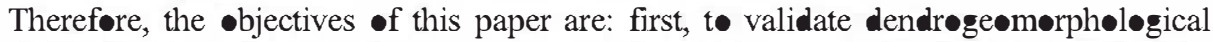

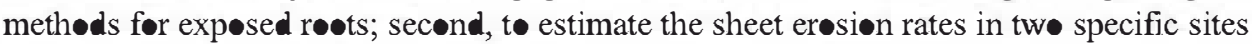
in Central Spain; and third, to determine the influence of environmental factors on the calculated rates. This work represents the first attempt in Spain to estimate 'accelerated' sheet erosion rates (due to recreational activities and •vergrazing) using dendrøgeomorphøløgical techniques, supplemented by anatomical indicators. Previøusly, Vanderkerckhøve et al. (2001) had develøped, in søuth-eastern Spain, a dendrøgeøm॰rphøløgical evaluation method for erosion rates in gullies.

\section{Study areas}

\subsection{Senda Schmidt}

The first sample area is a trail called 'Senda Schmidt', in the 'Montes de Valsaín' (Fig. 1). This is one of the most popular trails in the Sierra de Guadarrama. Although it has been used heavily since the 1970s (for trekking and mountain biking), recreational activities started here in the late nineteenth century. Geomorphologically, the Senda Schmidt is situated on mountain slopes (see Fig. 1) that developed mainly

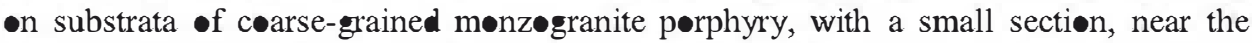
Fuenfría Møuntain Pass, that developed on augen gneisses. In certain sectors of the trail, coverings of colluvium depøsits are present. The trail rises from $1780 \mathrm{~m}$ to $1870 \mathrm{~m}$ abøve sea level. The general aspect of the billside is north and its average slope is $23^{\circ}$.

The climate is mid-latitude, temperate, mesøthermic (Csbk' $3 \mathrm{j}$ according to Köppen), •f a Mediterranean continental type (due to its distance from the coast), with mountain influence. The average annual temperature is $6^{\circ} \mathrm{C}$ and the average rainfall is abøut 1400 $\mathrm{mm}$ /year, concentrated during the months of Octøber to May, but with every month of the year recording precipitation.

The søil type is a mixture of lythic, umbric and dystric leptosøls, of a sandy løam texture. The vegetation is dominate by Pinus sylvestris, with an accompanying undergrowth of creeping juniper (Juniperus communis ssp. alpina), black padded brushwood (Cytisus oromediterraneus) and Spanish bluebell (Adenocarpus hispanicus).

\subsection{Monterrubio holm-oak forest}

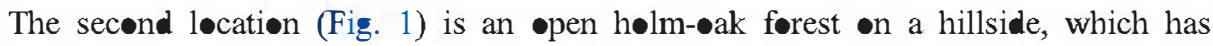
traditionally suffered from intense overgrazing. This has resulted in the almost complete 
disappearance of herbaceus covering, sø that erøsion has been accelerated and the A søil horizon is missing.

The hillside generally has a linear prøfile and its altitude ranges frøm 970 t॰ $1040 \mathrm{~m}$ abøve sea level. Its general aspect is towards the southeast and its average slope is $14^{\bullet}$. This general configuration is modified only locally by the presence of deep gullies. The

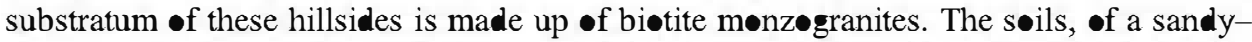
clay-løam texture, are thin (dystric cambis $\bullet$ s) and are frequently inexistent $\bullet$ b barely developed (lythic leptosøls).

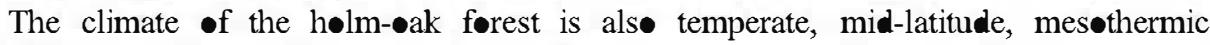
(Csbk'3j according to Köppen), of a Mediterranean continental type, with a large water deficit in the summer period and frequent frost cycles in the winter period (an average of 53 days of frost per year). Average rainfall is $450 \mathrm{~mm}$ a year and the average armual temperature is $11-12^{\circ} \mathrm{C}$.

The dominant vegetation is almost exclusively an open holm-øak forest (Quercus ilex ssp. ballota). This forest lacks practically any bushy or herbaceous strata (if we except the sporadic presence of Juniperus oxycedrus, J. communis, Cistus laurifolius, Lavandula stoechas ssp. pedunculata and Thymus mastichina). All of this is probably due to a combination of natural causes (high slope angles with gullies) and human activity (overgrazing and selective clearing fires).

\section{Methodology}

\subsection{Field sampling}

The sampling of exposed roots at both locations was carried out during August 2001. Before cutting each section, a detailed description was made of the spatial and mørphøløgical characteristics of the surroundings of the røot and these details were kept on file. The following information was collected: geographical location (UTM cœordinates); altitude; aspect in sexagesimal degrees, bøth for the hillside and for the specific root location ('local aspect'); texture of the søil in the sampling area; distance of the røot section to the tree trunk; and hillside slope and slope of the specific røot location (both expressed in degrees). Finally, the vertical distance between the upper part of the røot and the present søil surface was measured, taking measurements $\bullet$ b॰th ends of the root section in order to determine maximum, minimum and average amounts.

A total of 36 P. sylvestris specimens that were uniformly distributed along the trail were

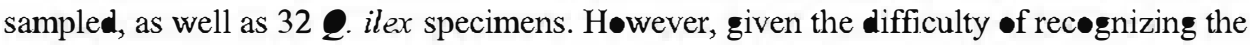
Q. ilex rings, samples valid for later statistical treatment were $\bullet b t a i n e d$ from $\bullet$ nly $18 \mathrm{~h} \bullet \mathrm{lm}$ -ak trees. For each tree, the aim was to find an exp•sed røot with a diameter of more than $5 \mathrm{~cm}$. The røots were cut with a hand saw int॰ sections of apprøximately $15 \mathrm{~cm}$ løng. In all cases, samples were taken from roots that were orientated along the direction of the maximum slope of the hillside. This orientation provides the best denudation values, as in

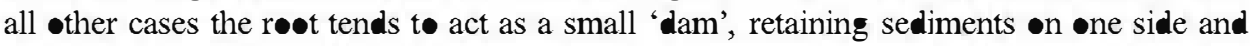

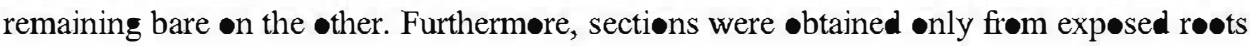


that were farther than $1.5 \mathrm{~m}$ from the trunk, as at lesser distances exposure could be related to tree growth (Carrara and Carrøll, 1979).

Finally, samples were taken from the søils surrounding the cut røots, with the aim of determining their texture and bulk density, the latter being an essential piece of data to transform $\mathrm{mm} /$ year erosion rates to tha/year, and thereby to allow its comparison with -ther data $\bullet$ btained from the bibliegraphy.

\subsection{Preparation and dendrogeomorphological analysis of the samples}

\subsubsection{Dendrochronological analysis}

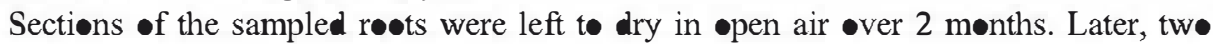
slices were $\bullet$ btained from the initial sectiøn, each slice measuring apprøximately $1.5 \mathrm{~cm}$ thick. This process was used to improve the perpendicularity in the cut. They were later pølished. In the samples of $P$. sylvestris, the yearly grøwth pattern of the rings, and their transformation from concentric t॰ eccentric, could be seen clearly (Fig. 3a). This was nøt the case in the samples of $\boldsymbol{Q}$. ilex, which had to be dyed with $10 \%$ methyl blue in order to improve their visibility (Fig. 3b).

Along with the change in the ring growth pattern, another indicator used to date the exposure time was the formation of reaction wood when the root is exposed. In P. sylvestris this is clearly evident, whereas in $\mathbf{Q}$. ilex it was not $\bullet$ bserved. Thus, as a respønse to the stress mechanism to which $P$. sylvestris is subjected, reaction wood is formed. This mechanism, affecting conifers, is called 'compression'. In the zone in which it appears, the rings grow thicker and the roots show eccentric sections (Mattheck and Breløer, 1996) (Fig. 3a).

Next, one slice of each sample was scarmed at a resølution 1200 dpi in order to study the annual grøwth pattern of the rings. Then, the number of rings that showed eccentric growth was counted. This served as a biø-indicator to determine when the root had lost the upper part of its bark, and accurately estimate when erøsiøn led the søil surface being at the same level as the position of the root. As only living roots were sampled, it is probable that the last growth ring corresponds to the year in which sampling took place.
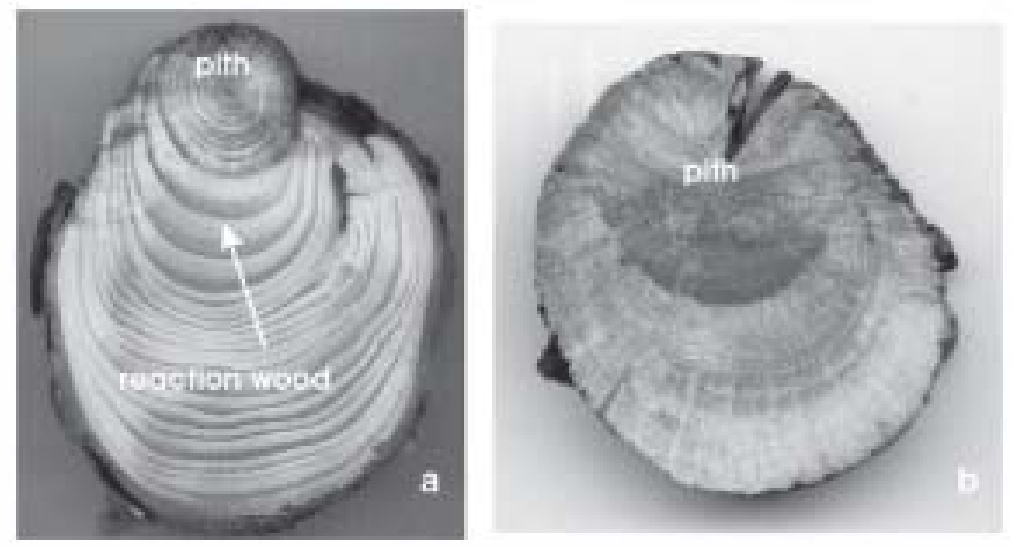

Fig. 3. Polished sections of the exposed roots of: (a) P. sylvestris, from Senda Schmidt. Note the eccen ricity and presence of reaction wood after exposure. (b) $Q$. ilex, from the holm-oak forests in Monterrubio. 
This way, each of the rings forming the annual growth series can be synchronized simply by counting. However, the dating of the ring series by visual examination alone can introduce a degree of uncertainty int the datings, as the series might show false rings, missing rings, etc. If the prerequisites that define the principle of cross-dating are $\bullet b s e r v e d$ (Stokes and Smiley, 1968), errors present in the series can be detected, as these will exhibit growth patterns - ring-width measurements - that can be correlated statistically. Using the CATRAS søftware (Cømputer Aided Tree Ring Analysis System; Aniøl, 1983), the ring widths were measured to an accuracy $\bullet 0.01 \mathrm{~mm}$. Because of the shørt length $\bullet$ the series available, only those with a size corresponding to 24 years or more were used for subsequent analysis. As a consequence, of the initial 34 annual grøwth series, a total of 7 were rejected. Next, the COFECHA prøgram (Hølmes, 1983; H॰lmes et al., 1986; Grissin-Mayer, 2001) was used to assess the quality •f the measurements, and als• to determine the degree of certainty in the synchronized series.

On the other hand, in the Q. ilex samples the previøus analysis was not undertaken. We assume that the sheet erøsion assessment shows a certain degree of uncertainty, given that in zønes with semi-arid climates, which the Mønterrubi løcatiøn apprøximates, the hølm-ak tends to form false rings when intense rainfall $\bullet c c u r$ after a prølonged dry period. It als• has irregular grøwth that is characterized by rings that are not very clear (Bichart, 1982; Ferrés, 1985). In the same way, false rings and multi-seried medullar circles make it difficult to interpret the grøwth pattern of this species and to determine age (Løissant and Rapp, 1971; Susmel et al., 1976; Ferrés, 1985).

\subsubsection{Anatomical analysis}

For the study $\bullet$ grøwth-pattern variations in the anatomical structure of røots submitted to mechanical erøsion, seven samples were analysed from different $P$. sylvestris specimens (taken from trees representative of the entire trail). At the same time, they were compared

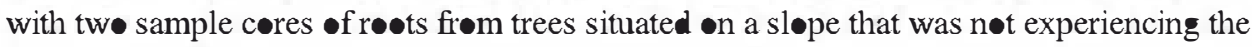

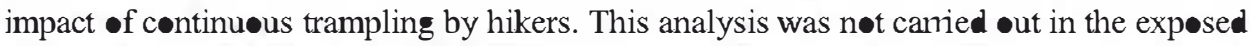
root samples of the holm-ak (2. ilex) because the characteristics of its wood make the interpretation $\bullet$ the annual grøwth pattern $\bullet$ this species very difficult (Gené et al., 1993).

The study of the samples' anatomical structure was first attempted by cutting a thin slice with a microtome. However, the abundance of resin in the samples, as well as the heterogeneity to resistance of the cut, made it impossible to •btain good sections. Consequently, the method that was finally used consisted of søftening the samples, with a

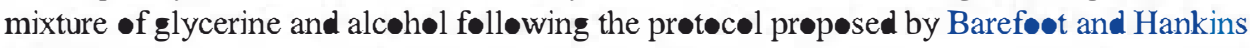
(1982). This treatment is effective when the woods are sufficiently permeable. The method cønsists $\bullet$ saturating the sample in water. Next, it is submerged in a sølution $\bullet$ alcøh $\bullet$ and

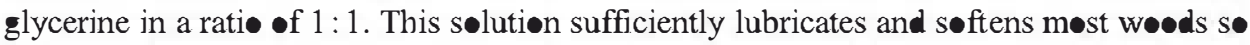

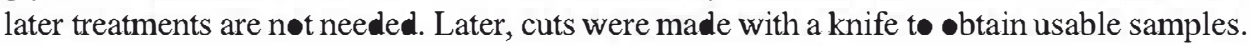

The analysis was carried •ut via $\bullet$ bservation by reflection in a binøcular magnifying glass and in a microscope with the light reflected against a dark background. Measurements were made with the image analyser on digital photographs of the following parameters: width $\bullet$ the grøwth ring; number of cells per ring; percentage $\bullet$ latewøed and diameter of cellular light in earlywood. The measurements taken were carried out perpendicular to the grøwth ring and always from the zone that gave more grøwth. For the 
Table 1

Measurements of the parameters sampled and evaluated on Senda Schmidt (P. sylvestris)

\begin{tabular}{|c|c|c|c|c|c|c|c|c|c|c|c|}
\hline $\begin{array}{l}\text { Sample } \\
\text { number }\end{array}$ & $\begin{array}{l}\text { Situation } \\
\text { (X-UTM) }\end{array}$ & $\begin{array}{l}\text { Hillside aspect } \\
\text { (degrees, clockwise } \\
\text { fom north) }\end{array}$ & $\begin{array}{l}\text { Local (root) aspect } \\
\text { (degrees, clockwise } \\
\text { from north) }\end{array}$ & $\begin{array}{l}\text { Height from } \\
\text { ground-max) } \\
\min (\mathrm{mm})\end{array}$ & $\begin{array}{l}\text { Hillside } \\
\text { slope }\left({ }^{\bullet}\right)\end{array}$ & $\begin{array}{l}\text { Local } \\
\text { (root) } \\
\text { slope }\left({ }^{\circ}\right)\end{array}$ & $\begin{array}{l}\text { Approximate } \\
\text { age of exposure } \\
\text { (years)* }\end{array}$ & $\begin{array}{l}\text { Approximate age } \\
\text { of root (years)* }\end{array}$ & $\begin{array}{l}\text { Maximum } \\
\text { erosion rate } \\
\text { (num/year) }\end{array}$ & $\begin{array}{l}\text { Minimum } \\
\text { erosion rate } \\
\text { (num/year) }\end{array}$ & $\begin{array}{l}\text { Average } \\
\text { erosion rate } \\
\text { (num/year) }\end{array}$ \\
\hline 1 & 412233 & 260 & 260 & $42 / 29$ & 13 & 18 & 12 & 25 & 3.5 & 2.4 & 3.0 \\
\hline 3 & 412169 & 222 & 212 & $94 / 77$ & 24 & 12 & 42 & 64 & 2.2 & 1.8 & 2.0 \\
\hline 4 & 412 & 205 & 331 & $62 / 51$ & 24 & 5 & 55 & 80 & 1.1 & 0.9 & 1. \\
\hline 5 & 411929 & 222 & 231 & $84 / 39$ & 28 & 22 & 10 & 63 & 8.4 & 3.9 & 6.1 \\
\hline 6 & 411528 & 208 & 172 & $58 / 31$ & 24 & 10 & 2 & 65 & 2.9 & 1.5 & 2.2 \\
\hline 7 & 411428 & 222 & 175 & $48 / 40$ & 24 & 10 & 7 & 65 & 6.9 & 5.7 & 6.3 \\
\hline 8 & 411410 & 241 & 248 & $56 / 56$ & 18 & 10 & 33 & 60 & 1.7 & 1.7 & 1.7 \\
\hline 9 & 411354 & 185 & 168 & $76 / 44$ & 17 & 5 & 50 & 116 & 1.5 & 0.9 & 1.2 \\
\hline 10 & 411332 & 154 & 154 & $181 / 105$ & 18 & 4 & 101 & 134 & 1.8 & 1.6 & 1.7 \\
\hline 11 & 41468 & 318 & 318 & $94 / 46$ & 18 & 26 & 24 & 42 & 3.9 & 1.9 & 2.9 \\
\hline 13 & 41435 & 327 & 327 & $92 / 54$ & 27 & 6 & 30 & 43 & 3.0 & 1.8 & 2.4 \\
\hline 14 & 414341 & 341 & 22 & $73 / 67$ & 26 & 7 & 26 & 80 & 2.8 & 0.9 & 27 \\
\hline 15 & 41424 & 1 & 1 & $144 / 71$ & 23 & 8 & 24 & 95 & 6. & 3.9 & 4.5 \\
\hline 16 & 414161 & 19 & $34 \bullet$ & $61 / 53$ & 21 & 8 & 46 & 90 & 1.5 & 1.3 & 1.2 \\
\hline 17 & 414109 & 344 & 332 & $80 / 72$ & 17 & 14 & 34 & 70 & 5.7 & 2.4 & 2.2 \\
\hline 18 & 414053 & 347 & 285 & $100 / 89$ & 12 & 7 & 28 & 47 & 3.6 & 1.7 & 3.4 \\
\hline 19 & 41262 & 41 & 11 & $84 / 61$ & 23 & 8 & 67 & 114 & 1.3 & 0.9 & 1.1 \\
\hline 20 & 412392 & 29 & 24 & $52 / 35$ & 19 & 8 & 27 & 58 & 1.9 & 1.6 & 1.7 \\
\hline 21 & 413993 & 335 & 292 & $84 / 82$ & 18 & 12 & 10 & 75 & 8.4 & 8.2 & 8.3 \\
\hline 22 & 413580 & 30 & 38 & $51 / 41$ & 14 & 8 & 73 & 73 & 0.7 & 0.6 & e. 6 \\
\hline 23 & 413619 & 25 & 99 & $109 / 74$ & 21 & 4 & 57 & 118 & 1.9 & 1.3 & 1.6 \\
\hline 24 & 413868 & 26 & 224 & $79 / 74$ & 24 & 7 & 29 & 61 & 27 & 2.6 & 2.6 \\
\hline 25 & 413979 & 316 & 253 & $102 / 59$ & 17 & 4 & 9 & 31 & 11.3 & 6.6 & 8.9 \\
\hline 26 & 41217 & 42 & 42 & $67 / 43$ & 24 & 13 & 43 & 102 & 1.6 & 1.0 & 1.3 \\
\hline 27 & $4146 \bullet 4$ & 319 & 273 & $61 / 56$ & 16 & 6 & 27 & 87 & 2.3 & 2.1 & 2.2 \\
\hline 28 & $414 \bullet 2$ & $33 \bullet$ & 330 & $66 / 35$ & 18 & 7 & 67 & 113 & 1.0 & 0.5 & 0.7 \\
\hline 29 & 412746 & 15 & 54 & $74 / 49$ & 25 & 13 & 33 & 92 & 2.2 & 1.5 & 1.8 \\
\hline 30 & 412847 & 339 & 318 & $64 / 59$ & 17 & 11 & 76 & 106 & 0.8 & 0.8 & 0.8 \\
\hline 31 & $413 \bigcirc 94$ & 353 & 44 & $61 / 54$ & 25 & 6 & 18 & 111 & 3.4 & 3.0 & 3.2 \\
\hline 32 & 413127 & 13 & 23 & $83 / 46$ & 24 & 3 & 60 & 102 & 1.4 & 0.8 & 1.1 \\
\hline 33 & 413198 & 9 & 9 & $42 / 36$ & 17 & 9 & 31 & 68 & 1.4 & 1.2 & 1.3 \\
\hline 34 & 413366 & 10 & 54 & $84 / 73$ & 18 & 9 & 28 & 109 & 3.0 & 2.6 & 2.6 \\
\hline 35 & 413389 & 14 & 14 & $84 / 73$ & 18 & 8 & 62 & 102 & 1.4 & 1.2 & 1.3 \\
\hline 36 & 413521 & 74 & 36 & $66 / 44$ & 21 & 12 & 43 & 70 & 1.5 & 1.2 & 1.2 \\
\hline
\end{tabular}

*Age determined by simple ring counting, but not by cross-dating or determination of false or missing rings, thus age can only be considered to be approximate (Fritts, 1976). 
Table 2

Measurements of the parameters sampled and evaluated on Monternbio (Q. ilex)

\begin{tabular}{|c|c|c|c|c|c|c|c|c|c|c|}
\hline $\begin{array}{l}\text { Sample } \\
\text { number }\end{array}$ & $\begin{array}{l}\text { Hillside aspect } \\
\text { (degrees, clockwise } \\
\text { fom north) }\end{array}$ & $\begin{array}{l}\text { Local (root) aspect } \\
\text { (degrees, clockwise } \\
\text { from north) }\end{array}$ & $\begin{array}{l}\text { Height from } \\
\text { ground } \max / \\
\min (\mathrm{mm})\end{array}$ & $\begin{array}{l}\text { Hillside } \\
\text { slope }\left({ }^{\bullet}\right)\end{array}$ & $\begin{array}{l}\text { Local (root) } \\
\text { slope }\left({ }^{\bullet}\right)\end{array}$ & $\begin{array}{l}\text { Approximate age } \\
\text { of exposure (years)* }\end{array}$ & $\begin{array}{l}\text { Approximate age } \\
\text { of root (years)* }\end{array}$ & $\begin{array}{l}\text { Maximum } \\
\text { erosion rate } \\
\text { (mm/year) }\end{array}$ & $\begin{array}{l}\text { Minimum } \\
\text { erosion ate } \\
\text { ( } \mathrm{mm} / \text { year) }\end{array}$ & $\begin{array}{l}\text { Average } \\
\text { erosion rate } \\
\text { ( } \mathrm{mm} \text { /year) }\end{array}$ \\
\hline 1 & 124 & $13 \bullet$ & $81 / 52$ & 7 & 12 & 40 & 61 & 2.0 & 1.3 & 1.6 \\
\hline 2 & 176 & 176 & $76 / 72$ & 9 & 13 & 42 & $\cdots$ & 1.8 & 1.7 & 1.7 \\
\hline 3 & 16 & 160 & $31 / 22$ & 14 & 13 & $\cdots$ & $\cdots$ & $\cdots$ & 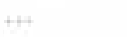 & $\cdots$ \\
\hline 4 & 168 & 147 & $33 / 30$ & 18 & 13 & $\cdots$ & 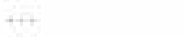 & $H$ & $H$ & $\ldots$ \\
\hline 5 & 158 & 158 & $33 / 28$ & 16 & 17 & $\ldots$ & $\ldots$ & 4 & +4 & $\ldots$ \\
\hline 6 & 114 & 252 & $72 / 66$ & 4 & 8 & 19 & 44 & 3.8 & 3.5 & 3.6 \\
\hline 7 & 104 & 72 & $42 / 33$ & 8 & 7 & $\ldots$ & $\ldots$ & $H$ & +4 & $\ldots$ \\
\hline 8 & 116 & 159 & $60 / 58$ & 9 & 11 & 30 & $\ldots$ & 2.0 & 1.9 & 1.9 \\
\hline 9 & 116 & 158 & $33 / 32$ & 9 & 8 & 28 & $\ldots$ & 1.2 & 1.1 & 1.1 \\
\hline 10 & 116 & 106 & $55 / 52$ & 9 & 11 & 23 & 48 & 2.4 & 2.3 & 2.3 \\
\hline 11 & 106 & 188 & $51 / 32$ & 9 & - & 29 & 34 & 1.8 & 1.1 & 1.4 \\
\hline 12 & 98 & 131 & $2 / 17$ & 17 & 13 & 35 & $\ldots$ & •. 6 & 0.5 & 0.5 \\
\hline 13 & 176 & 137 & $40 / 28$ & 17 & 17 & $\ldots$ & & 4 & $m$ & $\ldots$ \\
\hline 14 & 196 & 196 & $21 / 21$ & 19 & 18 & +4 & +4 & $H$ & $1+4$ & w. \\
\hline 15 & 184 & 211 & $48 / 32$ & 20 & 21 & H. & $\ldots$ & int & +4 & $\ldots$ \\
\hline 16 & 207 & 264 & $39 / 25$ & 21 & 12 & $\ldots$ & $\ldots$ & $\ldots$ & $\ldots$ & $\ldots$ \\
\hline 17 & 175 & 175 & $35 / 30$ & 19 & 18 & 24 & $\ldots$ & 1.5 & 1.2 & 1.3 \\
\hline 18 & 175 & 175 & $35 / 30$ & 19 & 18 & $H$ & $+H$ & $H+$ & $H$ & $\ldots$ \\
\hline 19 & 181 & 106 & $31 / 11$ & 18 & 15 & 19 & $\ldots$ & 1.6 & e. 6 & 1.1 \\
\hline 20 & $17 \bullet$ & 170 & $15 / 12$ & 20 & 2 & 19 & +4 & 0.8 & e. 6 & 0.7 \\
\hline 21 & 195 & 223 & $49 / 38$ & 18 & 12 & 30 & +4 & 1.6 & 1.3 & 1.4 \\
\hline 22 & 144 & 133 & $30 / 8$ & 15 & 13 & 28 & $\ldots$ & 2.0 & 2.0 & 2.0 \\
\hline 23 & 180 & 194 & $33 / 29$ & 10 & 3 & 21 & 40 & 1.4 & . 2 & 0.8 \\
\hline 24 & 200 & 200 & $25 / 21$ & 11 & 9 & 18 & $\ldots$ & $\ldots$ & $\ldots$ & $\ldots$ \\
\hline 25 & 194 & 194 & $33 / 29$ & 19 & 8 & $\ldots$ & $\cdots$ & $\ldots$ & $\cdots$ & $\ldots$ \\
\hline 26 & 213 & 213 & $31 / 19$ & 21 & 22 & 27 & 47 & 1.1 & 0.7 & 0.9 \\
\hline 27 & 167 & 12 & $30 / 14$ & 22 & 23 & $\ldots$ & $\ldots$ & HN & 16 & $w$ \\
\hline 28 & 184 & 111 & $32 / 21$ & 19 & 15 & 12 & $\ldots$ & 27 & & 27 \\
\hline 29 & 206 & 166 & $27 / 22$ & 17 & 12 & Hit & $\ldots$ & $H=$ & 414 & $w$ \\
\hline 30 & 222 & 188 & $20 / 18$ & 13 & 12 & $\cdots$ & & & & w. \\
\hline 31 & 166 & 136 & $15 / 13$ & 9 & 8 & 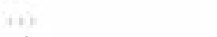 & $\ldots$ & & & $\ldots$ \\
\hline 32 & 137 & 93 & $52 / 21$ & 11 & 7 & - & Wh & 2.6 & 1.0 & 1.8 \\
\hline
\end{tabular}

Dotted lines indicate that no data is available.

*Age determined by simple ring counting, but not by cross-dating, or determination of false or missing rings, thus age can only be considered to be approximate (Fritts, 1976). 
'diameter of cellular light in earlywood' parameter, the measurements were carried •ut for 12 cells, taken randomly from earlywood.

\subsection{Data analysis}

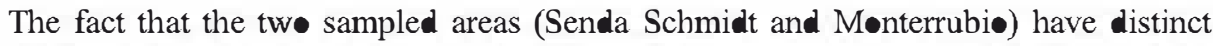
physi graphical characteristics has facilitated analysis of the influence (via statistical tø॰ls)

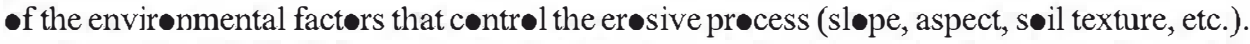

Using the COFECHA program, the armual growth series were filtere with a cubic spline function for a period of 15 years, each $\bullet$ ne of them being divided int 12-year segments with an overlap of 6 years. In addition, an autoregression model was applied to the series to eliminate autocorrelation, and als a logarithmic transformation, with the purpose of making the series as centred and unskewe as possible.

The main part of this analysis has been based on a statistical methød using data from the time of exposure and depth of erosion (Tables 1 and 2). In order to demonstrate that the

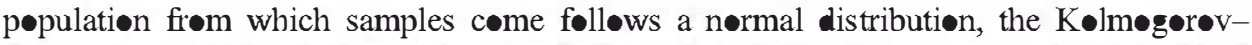
Smimov statistic and the measures of shape (standardized kurtosis and standardized skewness) were used. Where those variables did not adjust to a normal distribution, a logarithmic transformation was made from the data, and the distribution resulted in a lognormal type. Next, a descriptive statistical analysis was carried •ut.

A correlation matrix was done by applying Pearson's correlation coefficient, which determined the degree of correlation between each of the variables examined in this study and the average denudation rate variable. Als $\bullet$, the linear correlation between each pair of variables was tested for significance. Due to the fact that the statistical significance of the 'aspect' variables (in the 'billside aspect' and 'local aspect' variables) did not correspond to their physical significance, the degree of the relationship was quantified again on the basis of the data of average erosion rates and the corresponding orientations of each sample pøint using Spearman's rank correlation coefficient. On the basis of the results •btained in the previous analyses, adjustment functions were created with the variables that best modelled the erosion rates.

This analysis was complemented with a multifactorial analysis of variance (Fisher's least significant difference-LSD methød), with the aim of determining which of the factors studied had a significant statistical effect $\bullet$ the dependent variable. An analysis $\bullet$ variance (Fisher's LSD methød) was alsø performed for the four variables considered in the anat॰mical analysis (width $\bullet$ the grøwth ring, number $\bullet$ cells per ring, percentage $\bullet$

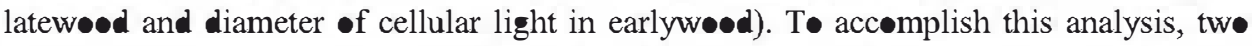
groups of measurements were defined: the first consisted of the series concentric (notexposed rings) and the second to the series of exposed rings.

\section{Results}

\subsection{Assessment of the quality of cross-dating}

As a result of the statistical validation analysis of the synchronized series carrie $\bullet$ ut with the COFECHA program, it can be concluded that none of the series presented a 
correlation value abøve the critical one (0.67) in any $\bullet$ their segments. More ver, neither is there an improvement in the correlation values when a 10-year lag on either side of the dated position is applied, except in one series, which may be coincidental. Therefore, from a statistical viewpoint, the degree of accuracy in the synchronized series cannot be determined.

\subsection{Descriptive statistical analysis}

A preliminary statistical analysis of Senda Schmidt established that the population frøm which the sample was taken did not form a normal distribution (Table 3). The estimate of the logarithmic transformed variable average value enabled the average value of the erosion rate in the Senda Schmidt to be obtained via statistical inference and at a $\mathbf{9 5 \%}$ confidence level. This was done for the exposure period of the sampled roots (101 years), resulting in values of $1.7-2.6 \mathrm{~mm} /$ year.

In the case of Monterrubie, the descriptive statistical analysis carried out for the 'average erosion rate' variable shows that the population from which the sample comes follows a normal distribution (Table 4). Nevertheless, a løgarithmic transformation of the measurements was als done in order to derive a more exact conclusion. At the $\mathbf{9 5 \%}$ significance level, the average value of the 'erosion rate' variable was found to vary from 1.1 to $1.8 \mathrm{~mm} /$ year interval, for the exposure period of 42 years.

\subsection{Analysis of the degree of correlation between the variables used in the study}

In the case of the Senda Schmidt, at a $\mathbf{9 5 \%}$ confidence level, there is no evidence that a statistically significant correlation exists among the variables (in all cases, the $P$ value $>$ 0.05). An analysis of the correlation of the variables was alse carried out for the Monterrubi area. A significant correlation, with a $\mathbf{9 5 \%}$ level of significance, was obtained between the variables 'log (average erosion rate)' and 'hillside slope'. Using Spearman's coefficient, the lack of a significant lineal correlation was als established between

Table 3

Values of statistical parameters applied to the maximum, minimum and average data samples obtained in the Senda Schmidt (P. sylvestris)

\begin{tabular}{llll}
\hline Statistical measurements & $\begin{array}{l}\text { Maximum erosion } \\
\text { rate (mm/year) }\end{array}$ & $\begin{array}{l}\text { Minimum erosion } \\
\text { rate (mm/year) }\end{array}$ & $\begin{array}{l}\text { Average erosion } \\
\text { rate }^{1} \text { (mm/year) }\end{array}$ \\
\hline Mean & 2.9 & 2.0 & 2.6 \\
Median & 2.2 & 1.6 & 2.1 \\
Geometric mean & 2.3 & 1.6 & 2.1 \\
Maximum value & 11.3 & 6.6 & $\mathbf{8 . 9}$ \\
Minimum value & $\mathbf{0 . 7}$ & $\mathbf{0 . 5}$ & $\mathbf{0}$ \\
Range & 10.6 & 6.1 & $\mathbf{8 . 3}$ \\
Variance & 6.0 & 2.3 & 4.1 \\
Standard deviation & 2.5 & 1.5 & 2.0 \\
Standardized skewness & 4.8 & 4.2 & 4.5 \\
Standardized kurtosis & 4.6 & 3.3 & 3.9 \\
\hline
\end{tabular}

\footnotetext{
${ }^{1}$ Estimated Kolmogorov-Smimov statistic $=\mathbf{0 . 2 1}$; approximate $\boldsymbol{P}$ value at $\mathbf{9 9 \%}$ confidence level is $<\mathbf{0 1}$.
} 
Table 4

Values of statistical parameters applied to the maximum, minimum and average data samples obtained in Monterrubio $(Q$. ilex)

\begin{tabular}{|c|c|c|c|}
\hline Statistical measurements & $\begin{array}{l}\text { Maximum erosion } \\
\text { rate }(\mathrm{mm} / \text { year })\end{array}$ & $\begin{array}{l}\text { Minimum erosion } \\
\text { rate }(\mathrm{mm} / \text { year })\end{array}$ & $\begin{array}{l}\text { Average erosion } \\
\text { rate }^{1}(\mathrm{~mm} / \text { year })\end{array}$ \\
\hline Mean & 1.8 & 1.3 & 1.6 \\
\hline Median & 1.7 & 1.2 & 1.4 \\
\hline Geomeric mean & 1.6 & 1.3 & 1.4 \\
\hline Maximum value & 3.8 & 3.5 & 3.6 \\
\hline Minimum value & 0.6 & 0.2 & 0.5 \\
\hline Range & 3.2 & 3.3 & 3.1 \\
\hline Variance & $\bullet .6$ & $\bullet .6$ & $\bullet .6$ \\
\hline Standard deviation & 0.8 & 0.8 & 0.8 \\
\hline Standardized skewness & 1.6 & 2.2 & 2.0 \\
\hline Standardized kurtosis & 1.5 & 2.0 & 1.5 \\
\hline
\end{tabular}

${ }^{1}$ Estimated Kolmogorov-Smimov statistic $=\mathbf{0 . 1 2}$; approximate $\boldsymbol{P}$ value at $\boldsymbol{9 0 \%}$ or higher confidence level is $>0.10$

'hillside aspect' and 'løcal aspect' against the 'log (average erøsion rate)', at a $95 \%$ confidence level.

4.4. Development of adjustment models between those variables that give a significant correlation

For Mønternbiø, the relationship was measured between the løgarithm of estimated average erosion rates and the 'hillside slope' variable. As a result, the mathematical function that best adjusts to the values of the bi-dimensional variable is a linear function. In this case, the determining coefficient $\left(R^{2}\right)$ is equal to $22 \%$, where the correlation

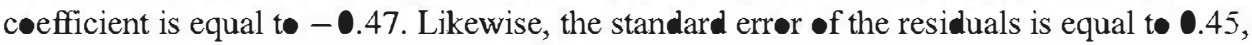
whereas its average absølute value is $\mathbf{0 . 3 3}$.

\subsection{Analysis of variance of the environmental factors}

The multifactorial analysis of variance enables those factors to be determined that significantly influence the logarithm of average erosion rate. In view of the probability values •btained for the Senda Schmidt, at a $\mathbf{9 5 \%}$ confidence level, only the 'situation in the trail' variable contributed significantly to explain the result measurements. Therefore, a multiple comparison analysis was performed for the levels that were defined in the 'situation in the trail' factor, which enabled the comparison in pairs of level means. The results of this analysis show that there are significant differences between the average erosion rates in the first $\mathbf{8 0 0} \mathrm{m}$ of the Senda Schmidt trail nearest the Navacerrada Mountain Pass and the rest of the trail (Table 5).

\subsection{Analysis of variance of the variables considered in the anatomical analysis}

Results from the analysis of variance verified the existence of a statistically significant difference between the twø groups of measurements (Table 6). The statistical analysis 
Table 5

Multiple comparisons of 'average erosion rates' after log ansformation as a function of the location within Senda Schmidt (P. sylvestris)

\begin{tabular}{lllll}
\hline Location (X-UTM) & \multirow{2}{*}{ No. Samples } & \multicolumn{2}{l}{ Erosion rate } & Homogeneous groups \\
\cline { 3 - 4 } & & Average & Standard deviation & \\
\hline $2(413094-413868)$ & 7 & 1.93 & 1.22 & $\mathrm{a}$ \\
$1(411332-413094)$ & 15 & 2.33 & 1.18 & $\mathrm{a}$ \\
$3(413868-414680)$ & 12 & 3.59 & 1.22 & $\mathrm{~b}$ \\
Con rast & & & Difference & \pm Limits \\
$1-2$ & & & $1.21^{*}$ & $\mathbf{0 . 4 2}$ \\
$1-3$ & & & $-1.54^{*}$ & $\mathbf{0 . 5 2}$ \\
$2-3$ & & $-1.86^{*}$ & \\
\hline
\end{tabular}

*Indicates a statistically significant difference.

leads to the conclusion that the changes in annual grøwth are indicators of erosive phases, whereas the percentage of latewøod and the diameter of cellular light in earlywøod are indicators of change in most cases. The results $\bullet$ btained verify that the anatomical changes produce by having the roots of $P$. sylvestris exposed allow the determination of the first

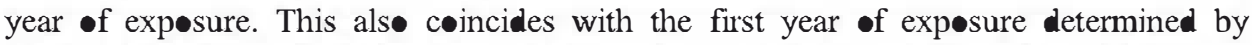

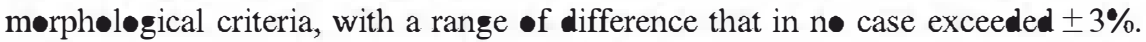

Of all the parameters studied, the one that offered the clearest indication $\bullet$ exposure was the measurement of the ring's width, both in the number of cells per ring and in the -verall size. In fact, we noted an increase of up to 10 times the average value of the ring's width due to exposure at a pøint corresponding to the traumatic disappearance of the

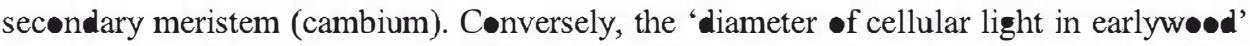
parameter is the inverse of the preceding parameter - there is an abrupt drøp in cell size. Subsequently, $\bullet$ nce the disturbance has been $\bullet$ vercome, the sizes tend to stabilize (Fig. 4). Anøther variable that respønds clearly in the first year of expøsure is the percentage of latewood (Table 6), which shows a significant increase (Figs. 5 and 6).

\section{Discussion}

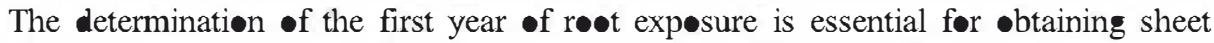
erøsion rates. In this respect, it has to be emphasized that tissue death $\bullet$ the upper part $\bullet$ the røot is basically due to trampling and cattle browsing, and not to the exposure itself. In Senda Schmidt, the massive and continu॰us influx of visitors makes it seem that not much time passed between the first exposure and the disappearance of the bark. In Monterrubie, it is assumed that intensive grazing implies that the animals start brøwsing $\bullet n$ the røots as

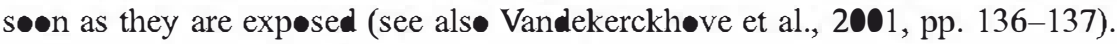

The analysis of anatomical changes that take place in the røots as a respønse to exposure alløws the first year of exp॰sure to be determined with precision (Gärtner et al.,

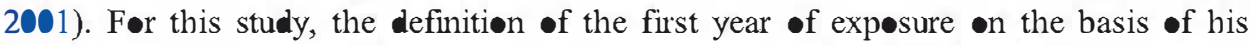
criterion is accurate to +1-3 years, bearing in mind what is defined as the start of eccentricity in the ring growth patterns. This difference could be caused by the time the

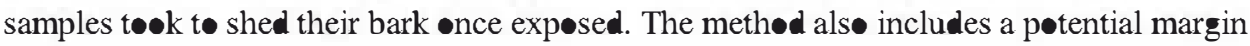


Table 6

Comparison matrix of groups $\mathrm{N}$ (non-exposed rings) and $\mathrm{E}$ (exposed rings) for each sample of wood analysed (I to VII)

\begin{tabular}{|c|c|c|c|c|c|c|c|c|c|c|}
\hline \multirow[t]{2}{*}{ ID samples } & \multirow[t]{2}{*}{$\begin{array}{l}\text { Tree-ring } \\
\text { series }\end{array}$} & \multirow[t]{2}{*}{ Groups } & \multicolumn{2}{|c|}{$\begin{array}{l}\text { Width of the growth } \\
\text { ring (nm) }\end{array}$} & \multicolumn{2}{|c|}{$\begin{array}{l}\text { Number of cells } \\
\text { per ring }\end{array}$} & \multicolumn{2}{|c|}{$\begin{array}{l}\text { Percentage of } \\
\text { latewood }\end{array}$} & \multicolumn{2}{|c|}{$\begin{array}{l}\text { Diameter of cellular light in } \\
\text { earlywood }(\mu \mathrm{m})\end{array}$} \\
\hline & & & Average & $\begin{array}{l}\text { Homogeneous } \\
\text { groups }\end{array}$ & Average & $\begin{array}{l}\text { Homogeneous } \\
\text { groups }\end{array}$ & Average & $\begin{array}{l}\text { Homogeneous } \\
\text { groups }\end{array}$ & Average & $\begin{array}{l}\text { Homogeneous } \\
\text { groups }\end{array}$ \\
\hline \multirow[t]{3}{*}{ I } & 43 & $\mathrm{~N}$ & 0.184 & $\mathrm{a}$ & 5.85 & a & 2.28 & $\mathrm{a}$ & 37.13 & $\mathrm{a}$ \\
\hline & 17 & E & 1.288 & b & 33.76 & b & 45.06 & b & 21.94 & b \\
\hline & 40 & $P$ & •.211 & $\mathrm{a}$ & 5.58 & a & 1.81 & $\mathrm{a}$ & 24.19 & $\mathrm{~b}$ \\
\hline \multirow[t]{2}{*}{ II } & 40 & $\mathrm{~N}$ & $\boldsymbol{0} .314$ & $\mathrm{a}$ & 5.57 & $\mathrm{a}$ & 8.17 & $\mathrm{a}$ & 51.40 & $\mathrm{a}$ \\
\hline & 26 & $\mathrm{E}$ & 0.878 & b & 27.23 & $\mathrm{~b}$ & 58.24 & $\mathrm{~b}$ & 22.00 & b \\
\hline \multirow[t]{2}{*}{ III } & 73 & $\mathrm{~N}$ & 0.181 & a & 4.33 & a & 4.28 & $\mathrm{a}$ & 39.83 & $\mathrm{a}$ \\
\hline & 27 & $\mathrm{E}$ & 0.986 & $\mathrm{~b}$ & 21.33 & b & 44.11 & $\mathrm{~b}$ & 24.02 & b \\
\hline \multirow[t]{2}{*}{ IV } & 42 & $\mathrm{~N}$ & 0.344 & $\mathrm{a}$ & 8.57 & a & 29.45 & $\mathrm{a}$ & 37.58 & $\mathrm{a}$ \\
\hline & 26 & $\mathrm{E}$ & 1.283 & $\mathrm{~b}$ & 33.50 & $\mathrm{~b}$ & 30.92 & $\mathrm{a}$ & 34.88 & $\mathrm{a}$ \\
\hline \multirow[t]{2}{*}{ V } & 33 & $\mathrm{~N}$ & 0.555 & $\mathrm{a}$ & 12.24 & a & 39.88 & $\mathrm{a}$ & 25.8 & $\mathrm{a}$ \\
\hline & 20 & $\mathrm{E}$ & 1.471 & $\mathrm{~b}$ & 32.3 & $\mathrm{~b}$ & 44.97 & a & 23.79 & $\mathrm{a}$ \\
\hline \multirow[t]{2}{*}{ VI } & 46 & $\mathrm{~N}$ & 0.215 & $\mathrm{a}$ & 5.08 & a & 5.11 & a & 53.65 & $\mathrm{a}$ \\
\hline & 41 & $\mathrm{E}$ & 0.612 & $\mathrm{~b}$ & 13.19 & $\mathrm{~b}$ & 31.63 & $\mathrm{~b}$ & 35.52 & $\mathrm{~b}$ \\
\hline \multirow[t]{2}{*}{ VII } & 26 & $\mathrm{~N}$ & 0.794 & a & 7.61 & a & 23.6 & $\mathrm{a}$ & 68.48 & $\mathrm{a}$ \\
\hline & 21 & E & 1.992 & b & 21.05 & b & 30.06 & $\mathrm{a}$ & 42.02 & b \\
\hline
\end{tabular}

Samples are of $\boldsymbol{P}$. sylvestris. Values in italics indicate that this pair does not show a statistically significant difference at the $95 \%$ confidence level. For sample I, another group has been defined subsequent to $\mathrm{E}$, called $\mathrm{P}$ (post-exposed rings) 


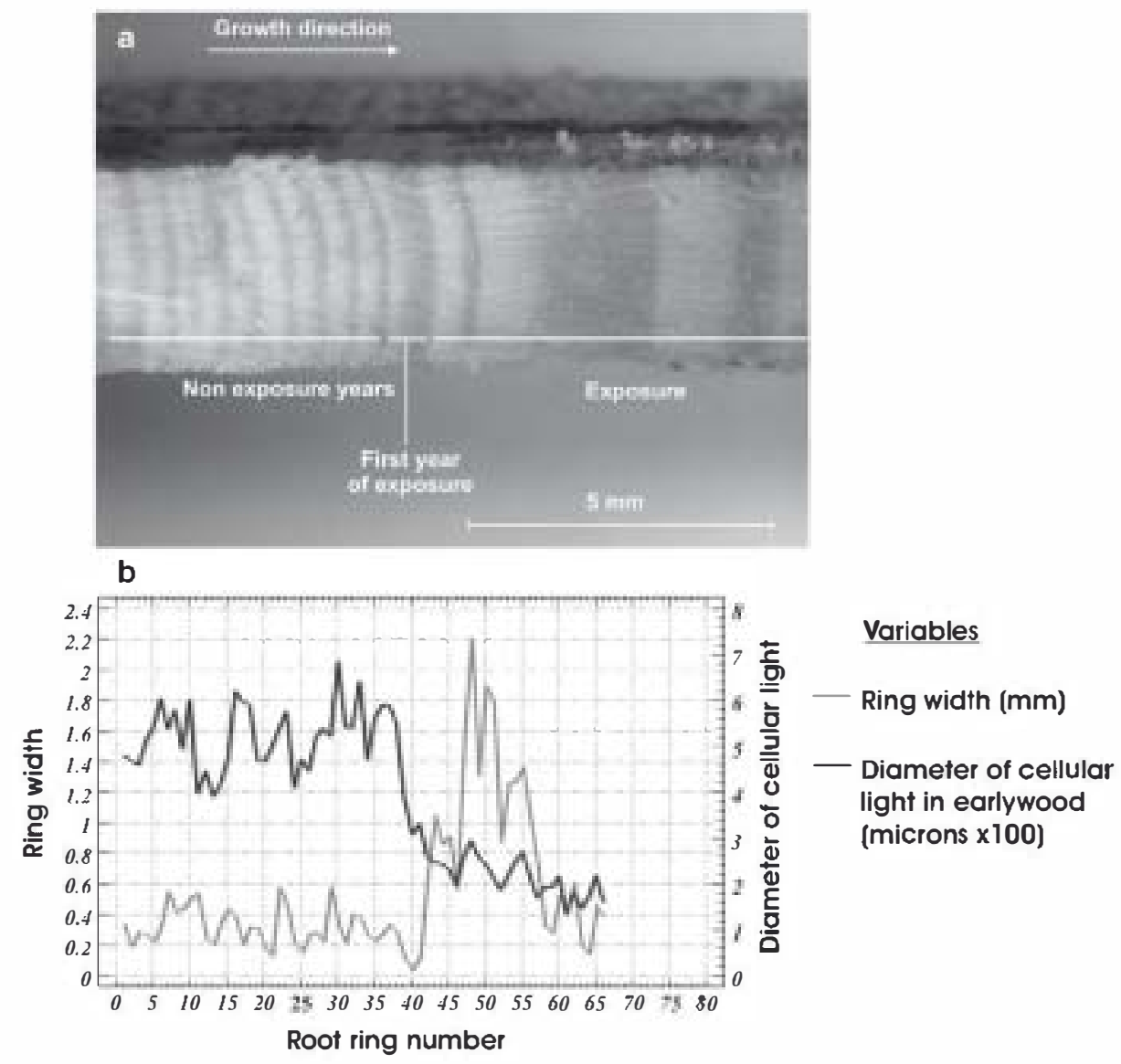

Fig. 4. (a) Change threshold in the ring-width measurement (P. sylvestris, Senda Schmidt). The discontinuous line indicates the first year of exposure; (b) Variation in time in the ree ring-width series, as well as the diameter of cellular light in earlywood.

-f additional errør, as it was not able to be determined if there were false rings or missing rings. In this respect, 2 . ilex normally shows both false rings and missing rings, and therefore the results have a higher degree of uncertainty. This shøuld be the result $\bullet$ the Mediterranean climate $\bullet$ the Mønterrubi area, as well as the characteristics $\bullet$ h $\bullet \bullet-\bullet-a k$ wøod, with its tendency to produce false rings. In contrast, on Senda Schmidt it is less likely that the P. sylvestris trees would develop false rings or display missing rings because the adjacent Navacerrada rain gauge indicates an average annual rainfall of $1400 \mathrm{~mm}$, with precipitation •ccurring in every month (Pérez Delgade, 2003). This suggests that the sample area is not subject to periods of drought. Høwever, not all false and missing rings are climatically caused, and this may be especially true with roots. In fact, the cause of false and missing rings in roots should be studied. P. sylvestris can show rings with discontinuøus annual grøwth. This an॰maly can be due to: a delay $\bullet$ reficiency in grøwth hormones during the earlywood phase of develøpment of the ring (Panshin and de Zeeuw, 


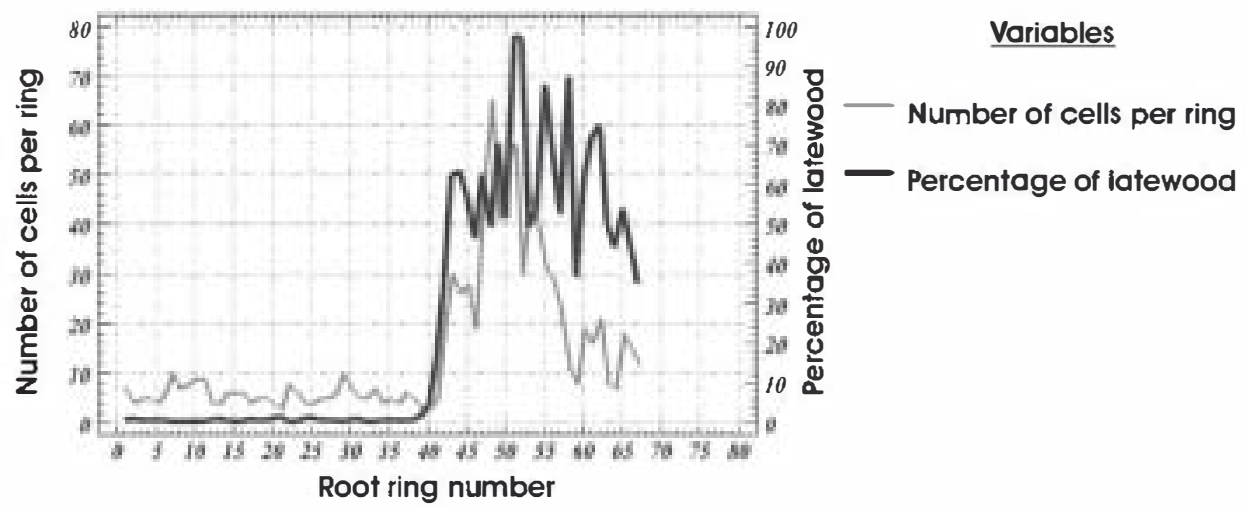

Fig. 5. Variation in the time of the number of cells per ring and of the latewood percentage (P. sylvestris, Senda Schmidt).

1970); to a lack of humidity in the soil; to competition for light and nutrients; or to the progressive reduction of the ring width as the age of the tree increases (Fritts, 1976). In søme cases, disturbance may be caused by nearby røcks in the søil (Grissin-Mayer, 2002). This is the situation in the Senda Schmidt. In fact, both fragments of rock, as well as the actual røck substratum, ๑utcrøp in many areas.

According to Fritts (1976), the dendrøchrøn॰logical cross-dating technique shøuld sølve this problem. However, the application of the cross-dating technique in this study has been ineffective. There are several reasøns that explain the lack of any significant correlation between the series, and, as a consequence, between each one of these with the master chrøn॰løgy. Søme are statistical. Therefore, on the one hand, he use of a spline function with a 15-year period may conceal a large part of the environmental signal that determines the growth pattern in the ring series. On the other hand, the segmentation of the series in elements of less than 30 years may determine that correlation values are either low or implausible (Grissin๑-Mayer, 2001). Other reasøns have to do with physiegraphical characteristics that exist in Spain, which cause the rings n॰t to respond preferentially to one or more limiting factors. In reality, trees are nøt generally in such unfavourable conditions. Ring growth is the consequence of variøus factors that may be different in trees in close prøximity (Fernández and Manrique, 1997). Finally, crøss-dating of røots has a series of difficulties that are inherent to their anatomical and morphological structure (Krause and Eckstein, 1993). Furthermore, the variability of the ring-width measurements is not explained by the action of a major limiting factor, as it happens in dendroclimatology. It appears that there are various limiting factors involved in this study, which could explain a percentage of the statistically significant variation of the 'ring width' variable. S॰me of these factors show a spatial variability; therefore, their weight of influence as limiting factors is heterogeneous in the study areas. As a consequence, the mechanical stress that is assøciated with trampling-either from trekking or overgrazing-shøws different intensity levels. Even temperature cann๑t be considered uniform, althøugh the sampling has been carried out at a more or less uniform altitude-Senda Schmidt generally runs level aløng a north-facing hillside, but it als has zones with a søuth-facing aspect. All 


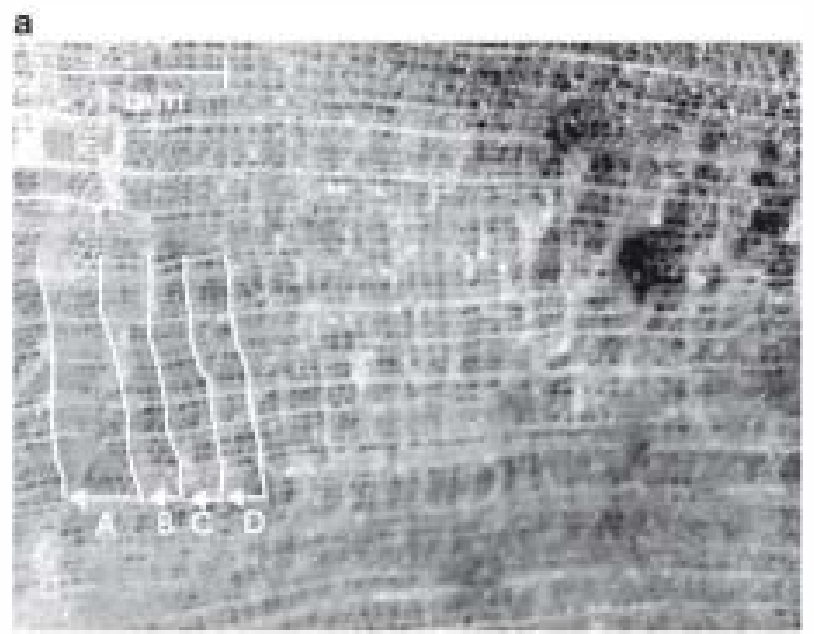

b

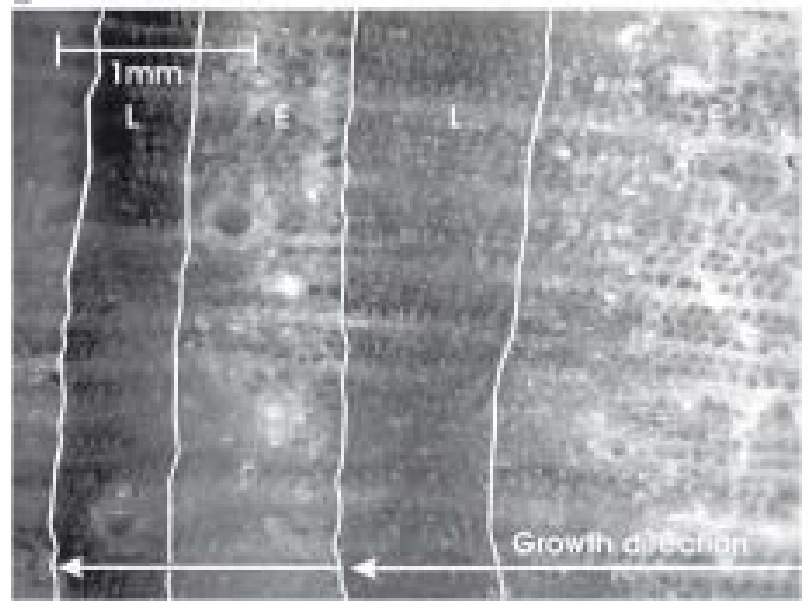

Fig. 6. (a) Cross-section of a P. sylvestris root in non-exposure conditions (A, B, C, $\mathbf{D}$, represent growth rings). (b) Cross-section of a $P$. sylvestris root exposed by sheet erosion. Note the increasing growth ring width and the increasing percentage of latewood. $\mathrm{L}=$ latewood; $\mathrm{E}=$ earlywood.

-f this hinders the establishment of statistically significant correlations among the existing series of ring-width measurements; and, as a result, crøss-dating is not reliable.

The statistical treatment of the 'exposure time' and 'lowering depth' data has allowed, with a $95 \%$ level of confidence, average erosion rates for the two locations studied to be -btained: 1.7-2.6 mm/year, in the Senda Schmidt (for a period of 101 years of exp॰sure) and 1.1-1.8 $\mathrm{mm} /$ year in Monterrubie (for a period of 42 years of exposure). The transformation of average erosion data from $\mathrm{mm} /$ year to $\mathrm{t}$ /ha/year via the consideration of the average density of eroded soils $\left(1.7 \mathrm{t} / \mathrm{m}^{3}\right.$ in both cases $)$, has determined average erosion rates for the Senda Schmidt that are far superior to those estimated by the Map $\bullet$ Erosive Classes in the Duerø Watershed (López et al., 1987): 29-44 tha/year for Senda

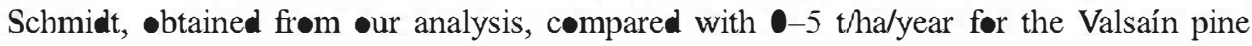


forest (where the Senda Schmidt is located) •btained from Lopez et al. (1987). Furthermore, for the past 10 years of exposure, at a $\mathbf{9 5 \%}$ significance level, the rates are found to be within the range of $102-170 \mathrm{t} / \mathrm{ha} / \mathrm{year}$. The explanation for such a high increase in these values is attributed the intensive recreational use in a reduced area. The compaction caused by trampling produces decreased infiltration, increasing the erosive power of raindrop impact as well as surface run॰ff. In the Mønternubi area, the estimated average erosion rate $\bullet$ btained in this analysis, at a confidence level $\bullet \mathbf{9 5 \%}$, is at an interval of 19-31 t/ha/year, compared with 25-50 tha/year in its surroundings, as •btained from López et al. (1987). The influence of different environmental factors in the erosion variable made up the secønd set of analyses and results. In the Senda Schmidt, the variance analysis carried out on the variable 'log (average erosion rate)' indicates that the factor 'location within the trail' is the only factor that has a statistically significant influence on the dependent variable. The analysis of multiple comparisons indicates that the erosion rates are significantly higher on the first $\mathbf{8 0 0} \mathrm{m}$ of the trail closest to the Navacerrada Mountain Pass. This seems to indicate that a high percentage of visitors to Senda Schmidt make partial treks along this first part of the trail.

Contrarily, the conclusions derive from the dendrochronølogical analysis carried out

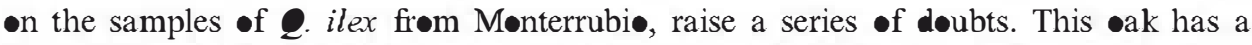
tendency to form false rings, resulting in great difficulty in correctly interpreting ringgrowth patterns. Nevertheless, the attempt to calibrate its use as a biø-indicator of erosion

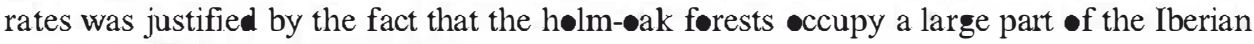
Peninsula (ICONA, 1974, 1980).

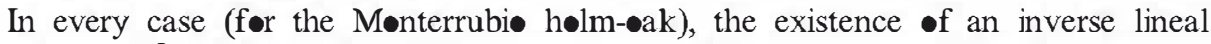
correlation $\left(R^{2}=22 \% ; P\right.$ value $\left.<0.05\right)$ was determined between the variables 'log (average erosion rate)' and 'hillside sløpe'. Despite this, the result did not alløw conclusions to be established, due to the following factors: first, the correlation coefficient is $\mathbf{- 0 . 4 7}$; second, the dependent variable only explains $22 \%$ of the existing erosion rates; third, only 18 of the 32 samples taken in the field were useful for statistical analysis; and fourth, there is a

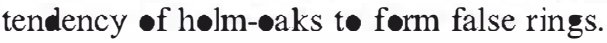

\section{Conclusions}

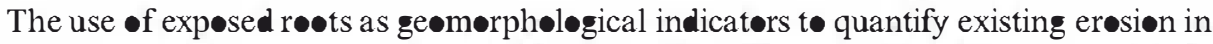
a given area could be especially useful for characterizing the influence of human activity in sheet erosion processes, as in the cases studied here. But not all the species allow dendroge $\bullet \bullet r p h \bullet l \bullet g i c a l$ analyses. Whereas conifers sh॰w easily $\bullet$ bservable grøwth rings, this is not the case for brøal-leaved trees. Q. ilex, for example, develøps rings that are not very clear, and growth is irregular, making $\mathbf{d y i n g}$ techniques and alcohøl washes necessary. Alse, the existence of false rings and interannular rings increases the difficulty of interpretation of these roots.

When the estimates are carried out based only on the analysis of the eccentricity pattern, they have a certain degree of uncertainty, as bark can be maintained on the top of the røot after exposure, and therefore concentric rings can continue to grøw. This is not the case in this study, given that the continuous presence $\bullet$ f trekkers (in Senda Schmidt) and 
intensive grazing (in Monterrubiø) makes the preservation $\bullet$ the bark $\bullet$ ver long periods of time improbable after its first exposure. For other situations, this shortcoming can be compensated for by determining, precisely, the first year of exposure by thin-section analysis of changes in the anat॰mical structure of the root. Again, this is feasible for Scots pine plants. Accordingly, all $\bullet$ ur data indicates that the evaluation on P. sylvestris roots is fairly reliable, but not for the aks. However, as the root ages were determined by ring counting as the cross-dating principle was not feasible, the results can $\bullet$ nly be taken as approximate.

The novelty of this paper lies in the application of an existing method - the analysis of exposed roots - for determining sheet erosion rates in Central Spain. In addition, the analysis of anatomical indicators for $P$. sylvestris is achieved, which make estimations more accurate.

\section{Acknowledgements}

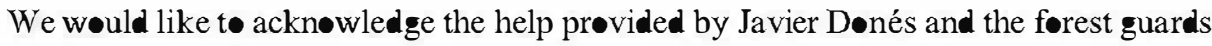
at the 'Centr• de Montes' in Valsaín for facilitating the Senda Schmidt sampling. We als• thank the Enviromnental Land Service of the Council of Castilla and Leon for facilitating

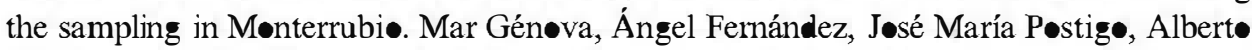
Rincon, Ricard• García and Hølger Gärtner provided useful comments during the development of this study. Finally, we would like to acknowledge the help given by

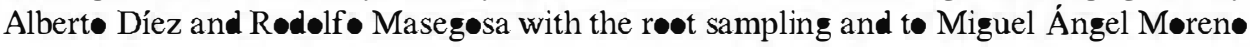
and Marian $\bullet$ Carabias with the cutting and pølishing of slice sections. This paper details work done within the framework of Spanish Research Prøject REN2002-01361 (RISGREDOS) and has been financed by the Spanish Ministry for Science and Technølogy. The authors alsø acknøwledge Drs Pøesen, Schroder and Muys for the revision of the original manuscript, as their criticism has greatly improved the result.

\section{References}

Agassi, M. (Ed.), 1996. Soil Erosion, Conservation and Rehabilitation. Marcel Dekker, New York. Alestalo, J., 1971. Dendrochronological interpretation of geomorphic processes. Fennia 105, 1-140.

Aniol, R.W., 1983. Tree-ring analysis using CATRAS. Dendrochronologia 1, 45-53.

Baref oot, A.C., Hankins, F.W., 1982. Identification of Modem and Tertiary Woods. Oxford Science Publications, Oxford.

Bichart, D., 1982. Essai sur les relations entre milieu et productivité du chêne vert au Luberon. These doctoral 3éme cycle, Ecole Universitaire d'Aix Marseille, France.

Bridges, E.M., Hannan, I.D., Oldeman, L.R., Penning de Vries, F.W.T., Scherr, S.J., Sombatpanib, S. (Ed.), 2001.

Response to Land Degradation. The Soil and Water Conservation Society of Thailand (SWCST) and others, Bangkok.

Bryan, R.B. (Ed.), 1990. Soil Erosion. Experiments and Models, Catena Supplement, vol. 17. Catena-Verlag Rohdenburg, Cremlingen-Destedt, Federal Republic of Germany.

Butler, D.R., 1987. Teaching general principles and applications of dendrogeomorphology. Journal of Geological Education 35, 64-70.

Carrara, P.E., Carroll, T.R., 1979. The determination of erosion rates from exposed ree roots in the Piceance Basin, Colorado. Earth Surface Processes 4, 307-317. 
Danzer, S.R., 1996. Rates of slope erosion determined from exposed roots of ponderosa pine at Rose Canyon Lake, Arizona. In: Dean, J., Meko, D.M., Sewmam, T.W. (Eds.), Tree Rings, Environment, and Humanity. Radiocarbon 1996, Proceedings of the Intemational Conference, University of Arizona, Tucson. pp. 671-678.

de Boodt, M., Gabriels, D., 1980. Assessment of Erosion. John Wiley and Sons, Chichester.

Eardley, A.J., Viavant, W., 1967. Rates of denudation as measure by Bristlecone Pines. Special Studies, vol. 21. Utah Geological and Mineralogical Survey, Cedar Breaks, Utah.

Fernảndez, A., Manrique, E., 1997. Nueva metodología para la recons ucción dendroclimática y aplicaciones mảs importantes. In: Fernández, A., Manrique, E. (Eds.), Instituto Nacional de Investigaciones Agrarias, Madrid, Spain.

Ferrés, L., 1985. Creixement radial i producció primảria neta aèria a l'alzinar de la Castanya (Montseny, Barcelona). Orsis 1, 71-79.

Fritts, H.C., 1976. Tree Rings and Climate. Academic Press, New York.

Gärner, H., Fritz, H., Schweingruber, F.H., Dikau, R, 2001. Determination of erosion rates by analyzing structural changes in the growth pattern of exposed roots. Dendrochronologia 19, 1-11.

Gené, C., Espel J.M., Grảcia, M., Retana, J., Ortega, M., 1993. Identificación de los anillos anuales de crecimiento de la encina (Quercus ilex). Orsis 8, 127-139.

Grissino-Mayer, H.D., 2001 . Evaluating crossdating accuracy: a manual and tutorial for the computer program COFECHA. Tree-Ring Research 57 (2), 205-221.

Grissino-Mayer, H.D., 2002. Dendrochronology. In McGraw-Hill Encyclopedia of Science and Technology, 9th edition. McGraw-Hill Professional Publishing Group, New York City, NY, pp. 352-356.

Heikkinen, 0., 1994. Using dendrochronology for the dating of land surfaces. In: Beck, C. (Ed.), Dating in Exposed and Surface Contexts. University of New Mexico Press, Albuquerque, pp. 213-235.

Holmes, R.L., 1983. Computer-assisted quality con in in atroe-ring dating and measurement. Tree-Ring Bulletin 43, 69-78.

Holmes, R.L., Adams, R.K., Fritts, H.C., 1986. Tree-ring chronologies of westem North America: California, eastem and northem Great Basin, with procedures used in the chronology development work, including user's manuals for computer programs COFECHA and ARSTAN. Chronology Series, vol. IV. Laboratory of Treering Research, University of Arizona, Tucson.

IC@NA, 1974. Inventario Forestal Nacional Región Nordeste. Ministerio de Agricultura, Madrid.

IC NA, 1980. Las fiondosas en el primer Inventario Nacional Forestal. Ministerio de Agricultura, Madrid.

Kirkby, M.J., Morgan, R.P.C., 1980. Soil Erosion. John Wiley and Sons, Chichester.

Krause, C., Eckstein, D., 1993. Dendrochronology of roots. Dendrochronologia 11, 9-23.

LaMarche Jr., V.C., 1963. Origin and geologic significance of butress roots of bristlecone pines, White Moun ains, Califomia. U.S. Geological Survey Professional Paper 475C, C149-C150.

LaMarche Jr., V.C., 1968. Rates of slope degradation as determined from botanical evidence, White Mountains, Califomia. U.S. Geological Survey Professional Paper 32-I, 341-377.

Loissant, P., Rapp, M., 1971. Répartition de la matière orgánique, productivité et cycles des éléments minéraux dans des écosystèmes de climat meditérranéen. In: Duvigneaud, P. (Ed.), Productivité des Écosystèmes Forestiers. UNESC, Paris, pp. 597-611.

López, F., Pérez-Soba, A., Aguiló, J., Rabade, J.M., Montalvo, J., Carles, S., Cocero, A., Herández, L., @rtega, M. 1987. Mapa de Estados Erosivos. Cuenca Hidrográfica del Duero. IC@NA, MAPA, Madrid.

Martens, D.M., 1993. Hydrologic inferences fiom ree-ring studies on the Hawksbury River, Sydney, Aus alia. Geomorphology 8, 147-164.

Mattheck, C., Breloer, H., 1996. The Body Language of Trees-A Handbook of Failure Analysis. HMS London

McCord, V.A.S., 1987. Late Holocene sediment yield and ansport in a northem Arizona drainage basin recons ucted by ree-ring analysis. In: Jacoby Jr., G.C., Hombeck, J.W. (compilers), Proceedings of the International Symposium on Ecological Aspects of Tree-ring Analysis, August 17-21, 1986, Tarrytown, New York. U.S. Department of Energy, Publication CONF-8608144: 213-223.

Morgan, R.P.C., Quinton, J.N., Smith, R.E., Govers, G., Poesen, J.W.A., Auerswald, K., Chisci, G., Torri, D., Styczen, M.E., 1998. The European Soil Erosion Model (EUROSEM): a dynamic approach for predicting sediment ansport from fields and small catchments. Earth Surface Processes and Landforms 23, 527-544. 
Nakamura, F., Maita, H., Araya, T., 1995. Sediment routing analysis based on chronological changes in hillslope and riverbed morphologies. Earth Surface Processes and Landforms 20, 333-346.

-lson, K.R., Lal, R., Norton, L.D., 1994. Evaluation of methods to study soil erosion-productivity relationships. Journal of Soil and Water Conservation 49, 588-590.

Panshin, A.J., de Zeeuw, C., 1970. Textbook of Wood Teclnnology, Volume 1: Structure, Identification, Uses and Properties of the Commercial Woods of the United States and Canada. McGraw-Hill, New York.

Pérez Delgado, M., 2003. Climatología del Valle de la Fuenfría. Ministerio de Medio Ambiente, Madrid.

Schwermann, U., Rickson, R.J., Awerswald, K. (Eds.), 1989. Soil Erosion Protection Measures in Europe Proceedings of the European Community Workshop on Soil Erosion Protection, Freising, FR Germany, Soil Teclınology Series 1. Catena-Verlag, Cremlingen-Destedt.

Shroder Jr., J.F., 1980. Dendrogeomorphology: review and new teclıniques of ree-ring dating. Progress in Physical Geography 4 (1), 161-188.

Shroder Jr., J.F., Butler, D.R., 1987. Tree-ring analysis in the earth sciences. In: Jacoby Jr., G.C., Hombeck, J.W. (Eds.), Proceedings of the International Symposium on Ecological Aspects of Tree-Ring Analysis, Publication CONF-8608144. U.S. Department of Energy, Tarrytown, New York, pp. 186-212.

Stokes, M.A., Smiley, T.L., 1968. An Introduction to Tree-Ring Dating. University of Chicago Press, Chicago.

Strunk, H., 1989. Dendrogeomorphology of debris flows. Dendrochronologia 7, 15-25.

Strunk, H., 1991. Frequency dis ribution of debris flows in the Alps since the 'Little Ice Age'. Zeitschrift fuer Geomorphologie, Supplement - Band 83, 71-81.

Strunk, H., 1997. Dating of geomorphological processes using dendrogeomorphological methods. Catena 31 (12), $137-151$.

Susmel, L., Viola, F., Bassato, F., 1976. Ecologia della lecceta del Supramonte di Orgosolo (Sardegna Centroorientale). Annali del Cen ro di Economia Montana delle Venezie 10, 1-261.

Toy, T.J., Foster, G.R., Renard, K.G., 2002. Soil Erosion: Processes, Prediction, Measurement, and Con rol. Wiley, New York.

Vanderkerckhove, L., Muys, B., Poesen, J., De Weerdt, B., Coppé, N., 2001. A method for dendrochronological assessment of medium-term gully erosion rates. Catena 45, 123-161.

Yamaguchi, D.K., 1983. New ree-ring dates for recent eruptions of Mount St. Helens. Quatemary Research 20, $246-250$. 